\title{
Peculiarities of police supervision in the sevenervice
}

\author{
DOI: $10.31551 / 2410-2725-2018-4-4-610-620$
}

\section{Shashaev Auezhan Kadirzhanovich}

Candidate of History, Leading Researcher in Ch.Ch. Valikhanov Institute of History and Ethnology of the Committee of Science of the Ministry of Education and Science of the Republic of Kazakhstan. Kazakhstan. E-mail: shashaevauezhan@mail.ru

\begin{abstract}
This article is devoted to the methods of police surveillance muslim population in Sevenrivers. In official papers, secret instructions and in circularic letters of the Police department, there were instructions on data gathering about frame of mind of a local population, its attitude to administration of the territory, what position they could accept in the international conflicts, whether an idea of independence was kept in memory, who was supported by youth, what could be expected from them in the future, who taught in schools and medreses, how many schools taught by new methods, how many teachers and pupils were in them, what subjects they taught, ets. Each year these objects of information were gathered through the secret agents, privately by policemen. One of such methods was eradication the ideas of independence, religions etc. from the memory of local population. The idea ofuselessness of resistance to police - administrative authority had to be strengthened in consciousness of native population.
\end{abstract}

Keywords: Turkistan; Sevenrivers; administrative authority; muslim population; police surveillance; schools; medreses.

\section{Полицейлік қадағалаудың жетісудағы ерекшеліктері}

\section{Шашаев Ауезхан Кадиржанович}

т.ғ.к., Қазақстан Республикасы Білім және ғылым министрлігі Ғылым комитеті Ш.Ш. Уәлиханов атындағы Тарих және этнология институтының жетекші ғылыми қызметкері. Алматы. Қазақстан E-mail: shashaevauezhan@mail.ru

Андатпа. Бұл мақалада Жетісулік мұсылман тұрғындарын бақылауға алудың полицейлік әдістәсілдері қарастырылады. Арнайы іс-құжаттарда, құпия нұсқауларда, сонымен қатар полиция департаментінің айналымдық хаттарында мынадай мәліметтерді жинау туралы бұйрық берілді: жергілікті тұрғындардың көңіл-күйі қайда ауады, аймақтағы билікке деген көзқарастары, халықаралық шиеленістер бола қалса олар қандай ұстанымда болады, өздерінің тәуелсіздігі туралы еске ала ма, жастарыкімді жақтайды, болашақта олардан не күтуге болады, мектептер мен медреселерде кімдер сабақ береді, жаңа тәсілдік мектептер қанша, оларда қанша ұстаз бен шәкірт бар, қандай пәндер оқытылады. Жыл сайын осындай мәліметтер полицияның құпия тыңшылары арқылы жиналатын. Осындай тәсілдердің бірі жергілікті тұрғындар санасындағы тәуелсіздіктені, діні және т.б. туралы естеліктерді жоюуға бағытталды. Халықтың санасына қарсыласудың мүлдем бекер екендігін сіңіруге күш жұмсалды.

Түйін сөздер: Түркістан; Жетісу;әкімшілік билік; мұсылман тұрғындары; полиция қадағалауы; мектеп; медресе.

\section{Особенности полицейского надзора в Семиречье}

\section{Шашаев Ауезхан Кадиржанович}

кандидат исторических наук, ведущии научный сотрудникИнститута истории и этнологи имени Ч.Ч. Валиханова Комитет науки Министерства образования и науки Республики Казахстан. Казахстан, Алматы. E-mail: shashaevauezhan@mail.ru Абстракт.В данной статье рассматривается методы полицейского надзора мусульманского
населения в Семиречье. В деловых бумагах, секретных инструкциях, а также циркулярных
письмах департамента полиции имеются указания о сборе данных об: умонастроении местного
населения, их отношении к админстрации края, какую позицию они могут принять В
международных конфликтах, сохранилась ли память о независимости, кого поддерживает
молодежь, чего можно ожидать от них в будущем, кто преподает в мектебах и медресе, сколько
новометодных школ, какие предметы и сколько учителей и учащихся в них обучается и т.д.
Каждый год эти сведения собирались негласно полицейскими через тайных агентов. Одним из
таких методов являлось икоренение из памяти коренного населения мысли о своей 
независимости, религи и т.д. В сознани народа укреплялась мысль о бесполезности сопротивления полицейско - админстративной власти.

Ключевые слова: Туркестан; Семиречье; админстративной власти; мусульманское население; полицейский надзор; мектеба; медресе.

\section{Удк/әОж 94(574)}

\section{Полицейлік қадағалаудың жетісудағы ерекшеліктері}

\section{А.К. Шашаев}

Кіріспе. Оңтүстік Қазақстанда соның ішінде, Жетісу жерінде отарлық кезеңдегі әкімшілік биліктің мұсылман тұрғындарын қатал бақылауға алғандығы мұрағат деректерінен айқын көрінеді.

Отаршылдық жүйенің атқарушы органы Полиция Департаментінің Верный қалалық сақшылар бөлімі арандатушылары мен құпия тыңшылары патша өкіметінің жарлықтарының орындалуы мен мемлекет тұғырына қауіп төнбеуін қадағалауға тиіс болды.

Әр түрлі айла-шарғылар арқылы тұрғындардың көңіл-күйі мен ісәрекеттерін анықтауға тырысты. Басты мақсат жазалаудың пәрменділігін арттыру үшін қылмыскерді табу керек болды. Жергілікті тұрғындар қадағалау мекемелері алдында үнемі қылмысты адамдай тартыншақтап жүруге тиіс болды. Полиция Департаментінің қол астындағы мекемелерінің қызметі осы мақсатқа жұмылдырылды. Міне сондықтан да осы мекемелердің қызметін деректер арқылы көрсету өзекті мәселенің бірі болып табылады.

Материалдары мен методтары. Бұл зерттеуді жазу барысында соңғы жылдары отандық тарих ғылымында болып жатқан түбегейлі өзгерістерді негізге алдық. Танымдық мүмкіндіктердің кеңеюуі зерттеу негізіне тарихи мәдени, өркениеттілік тәсілді қолдануға жол ашты. Әрбір өркениеттің өзіндік ерекшеліктерін тану, оның біртұтастығы, өзіне тән мәнге ие тұрақты жүйесі, өмірлік философиясы, құндылықтар жүйесі және тарихи - мәдени дәстүрлері, соған сәйкестендірілген халықтардың, жеке адамның өмірі, әлеуметтік және саяси институттары, ұлттық басымдылыққа ие ұстанымдар мен құндылықтарын неғұрлым терең танып білуге деген ұмтылыстарға жетелеуге әкеледі. Міне, осындай тәсілдерді пайдаланудың арқасында зерттеу көздерінің неғұрлым тиімді бағыттарға бет бұруына жол ашты. Атап айтқанда, зерттелуге алынған кезеңдегі оқиғалар мен фактілер нақты нысанға қатысты кешенді түрде сол дәуірмен байланыстырылып, ұлттық басымдылықтар мен құндылықтар тұрғысынан қарастырылып, соның негізінде оның мәні, негізгі ағымдарының бағыты және қоғамдық - саяси, әлеуметтік - экономикалық және халықтың рухани өміріндегі алатын маңызды зерттеудің өзегіне айналды.

Талдау.Патшалық Ресейдің Оңтүстік Қазақстандағы полицейлік қадағалау жүйесінің құрылуы мен қызметіне қатысты арнайы зерттеу жұмысы жүргізілмегенімен оның кейбір мәселелеріне қатысты ой-пікірлер XIX ғасырдың соңы мен XX ғасырдың бас кезінде жарық көрген еңбектерде көрініс тапты. Революцияға дейінгі және кейінгі Ресей, Қазақстан және шет ел тарихшыларының еңбегіне тарихнамалық шолу мен талдау жасалды.

Тель-Авивте 2001 жылы жарық көрген Е.Е. Лейзеровичтің «Социальные и экономические итоги Российской колонизации Туркестана» деген монографиясында отарлаудың әлеуметтік-экономикалық зардаптары, оның кеңестік кезеңдегі көрінісі берілген (Лейзерович, 2001). Қоныстандыру нәтижелері, отарлаудың халық санына тигізген әсері, мәдени-тұрмыстық 
өмірдегі олқылықтар, шаруашылықтың күйзелісі, дәстүрлі шаруашылықтың трансформациялануы, территориялық өзгерістер және т.б. мәселелер қарастырылған.

Вена университетінің профрессоры Андреас Каппелер зерттеуінде Ресейдің мұсылман елдеріне қатысты жүргізген саясаты сөз болған. Патшалық Ресейдің Түркістан өлкесіндегі мұсылмандарға қатысты жүргізген саясатының негізгі екі жолы болды. Оның біріншісі агрессивтік (зорлық, күштеу) болса, екіншісі прагматикалық (майысқақ, жұмсақ) болды деп көрсетеді.

Негізгі деректердің дені Қазақстан Республикасы Орталық Мемлекеттік Мұрағатының қорларынан алынды. Мысалы, 65 - Полиция басқармасының Жетісу Жандармдық бөлімі деген қорда жандармдар бөлімшесіне қатысты бұйрықтар, ережелер, айналымдық хаттар және қылмыстық істер, саяси партиялар, әр түрлі іздестіру шаралары жөніндегі мәліметтер бар. Жандармдар бөлімшесіне қатысты мәліметтер: 726 - Жандармдық полиция басқармасы бастығының көмекшісі; 82 - Полиция басқармасының Шымкент бөлімшесі; Өзбекстан Республикасы Орталық Мемлекеттік Мұрағатының 468 - Ташкент темір жолы полиция басқармасы жандармы; 477 - Орта Азия темір жолы полиция басқармасы жандармы қорларында сақталған.

Полиция департаменті мен жандармдар бөлімшесіне және тағы басқа өлкедегі полиция мекемелеріне қатысты мәліметтерді 64 - Дала генералгубернаторының кеңсесі; 383 - Сырдария облысы қырғыздары басқармасы; 382 - Сырдария облысы қолбасшысы басқармасы; 385 - Жергілікті мекенжайлар басқармасы кеңсесі; 44 - Әскери министрліктің Верныйдағы Жетісу облыстық басқармасы; 46 - Жетісу облысы әскери штабы; 780 - Соғыс министрлігінің әскери бастығы басқармасы қорлары мен Өзбекстан Республикасы Орталық Мемлекеттік Мұрағатының И-1 - Түркістан генералгубернаторлығының кеңсесі; И-17 қор - Сырдария облыстық басқармасы қорларынан қосымша мәліметтер алынды. Бұл мәліметтер бұрын зерттеу көзі болмағандықтан оларды өңдеп, жүйеге келтіріп саяси полицияның басты мекемесі жандармдар басқармасының қызметін талдауға қолдандық.

Верный қаласындағы полиция мекемелерінің қызметі мен әдіс-тәсілдері жөніндегі мәліметтер, 51 - Верный қалалық полициясы; 52 - Верный қаласы полиция бөлімінің бірінші приставтығы деп аталатын қорларында сақталған. Верный полиция басқармасының ісқағаздарын ревизиялау, өкімет мекемелерінің жарғылары, ережелер, Верный қалалық полиция басқармасы қызметкерлерінің тізімі, құпия хаттар, тыңшылық мәліметтер және т.б. деректер де қарастырылды.

Үлкен бір мәлімет көздері - құпия деп аталатын 73 «с» - Жетісу облысы, Верный қаласы іздестіру пунктінің меңгерушісі деген қорда кездеседі. Мұнда жеке адамдардың саяси сенімділігі жөнінде, социал-демократиялық топтар жайында, губернаторлар туралы мұсылмандық қозғалыс, полицияның өзі жайында астыртын жиналған құпия тыңшылардың мәліметтері мен олардың кейбіреулерінің жеке құжаттары сақталған.

Түркістан өлкесіндегі приставтық мекемелер туралы 145 - Түркістан бөлімшелік приставының басқармасы; 52 - Верный қаласы бірінші полиция бөлімшесінің приставтығы; 236 - Жүлек бөлімшелік приставтығы; 47 - Верный уезінің аға бөлімшелік приставтығы; 237 - Жаркент қалалық приставы; 54 Верный уезінің Зайцев бөлімшесі приставы; 748 - Асы бөлімшесі приставы; 691 - Меркі бөлімшесі приставы; 768 - Шымкент уезінің үшінші бөлімшелік приставы; 53 - Верный қаласы, екінші полиция бөлімшесінің приставы қорларының мәліметтері үлкен деректер көзі болып табылады. 
Түркістан аудандық сақшылар бөлімінің құрылуы оның бөлімшелері, негізгі қызметі мен жұмыс істеу тәсілі жөніндегі аса көп мәліметтер Өзбекстан Республикасы Орталық Мемлекеттік Мұрағатының 461 - Түркістан аудандық сақшылар бөлімінің қорынан алынды. Сол сияқты Ташкенттегі осы мұрағаттың 462 - Қаланың орыстар тұратын бөлігінің полиция басқармасы; 463 - Қаланың ескі бөлігінің (бұратаналар тұратын) полиция басқармасы; 467 - Түркістан аудандық сақшылар бөлімінің, Верный іздестіру пункті қорлары полиция мекемелерінің жеке бір бөлімшелері бойынша жинақталған мәліметтерге толы. Қазақстан Республикасы Орталық Мемлекеттік Мұрағатының 251 - Перовск уезі үшінші бөлімшесінің билер соты; 261 - Ташкент аймақтық сотының, Қазалы уезі екінші бөлімшесі билер соты; 91 - Жаркент уезі бірінші бөлімшесінің билер соты; 119 - Ішкі істер министрлігінің Түркістан уезі бойынша істері қорларында полиция мекемелерінің әрекеті мен оның қызметкерлері тарапынан орын алған тәртіп бұзушылық мәселелеріне қатысты мәліметтерге толы. Міне жоғарыда айтылған архив қорларының мәліметтері осы мақаламызды жазуға үлкен септігін тигізді.

Нәтижелері. Оңтүстік Қазақстанда соның ішінде, Жетісу жерінде отарлық кезеңдегі әкімшілік биліктің мұсылман тұрғындарын қатал бақылауға алғандығы мұрағат деректерінен айқын көрінеді.Патшалық Ресейдің сақшылар бөлімінің тыңшылары арқылы алуға ынталы болған мәліметтері ең алдымен мұсылмандық қозғалыс жайында болды. Мұрағаттың құпия қорларының бірінде жеке жандармдар корпусының ротмистрі В.Ф. Железняковтың мәліметі сақталған. Онда «тыңшы "Гардъ" (шын аты Габдулали Сангатула Юнусов) магазинде ет сатушы қызметін атқарып мұсылмандық қозғалыс жайында мәлімет жинайды. Оған 40 руб. жалақы төленді»- деп баяндайды ${ }^{1}$.

Деректерде «Слива», «Смелый», «Сметливый» деген жалған атпен Верный сақшылар бөлімінде қызмет атқарған Аристов, Кучинов, Семенов және басқалардың әр түрлі мәліметтері сақталған ${ }^{2}$. Жетісу жеріндегі сақшылар бөлімінде қызмет атқарған тыңшылардың жергілікті мұсылман тұрғындарына қатысты жүгенсіздік әрекеттері полиция департаменті бойынша жіберілген айналымдық (циркулярное) хаттары арқылы көрініс береді. Жандармдар корпусы ротмистрі Астраханцевтің мәліметінде олардың (тыңшылардың) өз әрекеттеріне жауапсыз қарайтындығы, маскүнемдігі, анықталмаған мәліметтер беретіндігі, төбелес-кикілжіңдерге жақындықтары және өздерін әшкерелеп қоятындығы жайында айтылады ${ }^{3}$. Қызмет бабын пайдаланып, тұрғындарға қатысты күш көрсету жағы да орын алып отырған. Оның бір мысалы ретінде Түркістан генерал-губернаторына Верный қаласының тұрғыны Құрбан Ходжиев Махмуд-қажының батыс - Талғар ояздығы қазақтары атынан жазған арызын келтірдік: «Верный қаласында тұратын мұсылмандардың басына түскен ауыр жағдай маған қолыма қалам алғызып төмендегіні баяндауды міндеттейді»- дей келіп, бұрыннан Верный қаласында Наманғандық сарт Закирбай Исабаевтың тұратындығын айтады ${ }^{4}$. Ол бастапқыда ұсақ саудамен айналысып, кейінірек саудасы жүрмей, тақыр кедей болып қалады. Верный қаласының полицмейстрі қызметіне штаб-ротмистр Поротников (кейін пара алғаны және жүгенсіздігі үшін жұмыстан қуылған) отырған соң, Исабаев пысық адам ретінде полицияға құпия тыңшы болып қабылданады. Осы салада екі-үш ай қызмет еткеннен кейін,

\footnotetext{
${ }^{1}$ Қазақстан Республикасы орталық мемлекеттік мұрағаты (бұдан әрі -ҚРОММ). 41 қ., 1 т., 226 іс, 141 п.). 'ҚРОММ. 73 «с» құпия қоры, 2 т., 2 іс, 3 п.

${ }^{3}$ ҚРОММ. 73 «С» К., 2 т., 2 iс, 7 п.

${ }^{4}$ ҚРОММ. 73 «с» K., 2 т., 2 iс, 15 п.
} 
полицмейстрге қай қылығымен жаққанын, әйтеуір оны Қашқарлық сарттардың ақсақалы етіп бекітеді. Деректерге жүгінер болсақ, бұған не халықтың келісімі, не әскери губернатордың бұйрығы берілмеген. Соған қарамастан осы қызметте Закирбай Исабаев екі жыл жұмыс істеп, өзін тек жаман жағынан ғана көрсетті. Халықтан әр түрлі салықтар жинап, ауқатты адамдардан пара талап етті. Пара бермегендерді саяси сенімсіз ретінде полицияға ұстатамын деп бопсалады, оған көнгісі келмегендерге, осы айтқанын іске асырды.

Өзіне бағынышты Қашқар сарттарын тонаудан басқа, мұсылман тұрғындарының барлығының ісіне араласты. Оның бас сұқпайтын ісі болмады, олар жайында үнемі полицияға өз баяндауын беріп отырды. Оның өтініштерін полицмейстр Поротников еш қарсылықсыз орындайтын.

Арызда осы мәселелер айтылып, бұл тұрғындардың ашу-ызасын келтіріп отырғанын, оған қарсы шаралар қабылданбағандығы, полиция бастығының керісінше өз қызметкеріне көмек көрсетіп, қолпаштап отырғандығы айтылады.

Ал, Исабаевтың құпия қызметкер екендігінің шындығын, мұрағат қорынан алынған Верный қаласы мен Жетісу облысы іздестіру пунктінің берген анықтамасы дәлелдейді5.

Құпия қорларда Исабаев Закирбайға қатысты бірнеше құжат сақталған. Біріншісі, жеке жандармдар корпусының ротмистрі Астраханцевтің бұйрығы: «1913 жыл, 1 шілде, жұма. Мен - жеке жандармдар корпусының ротмитрі Астраханцев, келіп түскен құпия мәліметтер бойынша, тараншылар Садыбек Бүшіриев және Тұрсын Тұрдиевтің ақсақал Закирбай Исабаевқа қарсы лаңкестік әрекет жасамақ болғандығы, бірақ бақытымызға орай жүзеге аспай қалғандығын анықтадым. Оның жүзеге асу мүмкіндігі барлығын ескере отырып бұйырамын, Бүшіриев пен Тұрдиевті ұстап, Верный қаласы түрмесіне қамалсын» ${ }^{6}$.

Осы құжаттың 32 парағында олардың 5 шілдеде ұсталып, Мемлекет қауіпсіздігі ережесінің 21 бабына сай, түрмеге қамалғаны айтылады. Құпия тыңшылардың мәліметі бойынша қастандық жасаушылардың мақсаты полицмейстр мен қала ақсақалы Исабаевты өлтіру болған. Деректерді мұқият зерттей отырып бұл айыптардың әдейі ұйымдастырылған арандату әрекеті екендігі байқадық.

Іздестіру бөлімінің берген анықтамасында қастандықты ұйымдастырушылар мен жүзеге асырушылардың тізімінде мына адамдар көрсетілген:

1. Абдрахманов Пірімқұл. Ташкенттік сарт, 65 жаста, саудагер. Верный қаласында тұрады.

2. Мәуленқұлов Көбілжан. Маргеландық сарт, 44 жаста, саудагер.Верный қаласында тұрады.

3. Бүшіриев Садыбек. Қарасу болыстығы, тараншы, 38 жаста, саудагер. Верный қаласында тұрады.

4. Тұрдиев Тұрсын, Қарасу болыстығы, тараншы, 41 жаста, ұста. Верный тұрғыны.

5. Абдрахманов Райымқұл. Ташкенттік сарт, 23 жаста, Верныйтұрғыны.

6. Триерст Давид Яковлевич, бұрынғы Верный қаласы аймақтықсотының жеке істерімен айналысқан сот қызметкері.

Мәлімет бойынша 1913 жылдың шілдесінде Верный арестант бөлімінің лазаретінде (біздің топшылауымыз бойынша, сірә, соққыға жығылып емделуге 
жіберілген) жатқан Абдрахманов Пірімқұл, Мәуленқұлов Көбілжан, Абдрахманов Райымқұл (Пірімқұлдың ұлы), Триерстің ақылымен (арандатушы болуы мүмкін) полиция бастығы мен қала ақсақалы Исабаевқа қарсы қастандық жасауды көздейді. Оларды өлтіруге жалдау үшін қайсарлығы және батылдығымен көзге түскен Бүшіриев Садыбек пен Тұрдиев Тұрсынға тоқталады.

1914 жылдың қаңтарында Верный жандармдар корпусының ротмистрі Соколов, Түркістан аудандық сақшылар бөлімі бастығының бұйрығына сай Бүшіриев пен басқалардың да саяси сенімділігін анықтауды одан әрі жалғастырған.

Жетісу облыстық прокуратурасының «Пішпек ояздығындағы 1898жылғы қырғыздардың (қазақ) көтеріліске шықпақ ойын» тексеру барысында мына мәселелер анықталды: Осылай деп арыз берген шаруалар Яков Мумелков, Иван Прокопьев және Степан Пойдиннің мәліметтерін тексеру барысында, қазақтар арығындағы суды емін-еркін пайдалану үшін және олардың әлсіз қарсылығын болдырмау үшін жала жапқандықтары анықталды. «Олар, қазақтар үкіметті балағаттап, орыс шаруаларын қырып саламыз деп айтты дейді. Шаруалардың бұл айтқандарының жаны жоқтығын қазақтар айтып отыр, олай дейтін себебіміз қырғыздардың көпшілігінің маған берген түсінігінде (тергеуші Игнатев) орыс шаруаларықырғыздардың арығындағы суларын өз қалауларынша пайдаланғысы келгендіктен, қарсылық көрсеткендерге, орыс үкіметіне қарсы бүлік ұйымдастырды деген жала жабамын деп қоқан-лоққы жасауында екен». Сонымен тексеру қорытындысы бұл арыздардың қазақтар үстінен жабылған жала екендігін анықтады, нәтижесінде іс тоқтатылды.

Міне, осындай істердің бірнешеуін келтіруге болады. Қапал ояздығының орта шаруасы Шаяхмет Мұстафиннің, трактирде орыс өкіметін балағаттағандығы, Балғалы болыстығының тұрғыны Есенбай Жүрбаевтың Илек ауылы орыстарын, Кәрібжан Байсақовтың (шалғынға таласып) барлық орыстарды қырып саламын дегені прокуратура жағынан тексеріліп, дәлелденбеу себепті істері тоқтатылған. Орыс шаруаларының бұл бассыздық әрекетіне жол берген жергілікті полиция өз тарапынан бұрын соңды Ресей империясында болмаған жүгенсіздіктерге барды, тежеусіз тонаулар мен арсыздықтарға, күштеуге жүгініп пара алды. Қатардағы орыс полиция қызметкерлері ақшалай да, кез-келген қазақтың әйелін тартып алумен де, өз қажетіне сай күшке жүгініп отырды. Егер қарсылық көрсеткендер болса ұрыпсоғып, қылышпен шапты, атып өлтірді, яғни ойына келгенін істеді. Олардың үстінен шағымданғандардың арызын полиция бастықтары басып тастап отырды. Оңтүстік Қазақстандағы полиция қызметкерлері Ресейден әр түрлі жағымсыз қылықтары үшін жазаға ұшырағандар қатарынан толықтырылған еді. Жетісу жеріндегі полиция қызметінің басты бағдары мен әдіс тәсілдері де өзінің аса қатыгездігімен көрінді. Жоғарыда айтылғандай орыс шаруалары қазақтардың жерін жайлап, суын пайдаланып, шалғындарын өз меншіктеріндей иемдене отырып, оларды заңмен қорқытып, үнсіз мойын ұсынуларын қалаған еді. Қарсылық көрсеткендер аяусыз жазаланды.

Заң орындары ең алдымен орыс шаруасының мүддесін қорғады. Орыс шаруаларының бассыздығының тым шектен шығып кеткендігі соншалық, заң орындары, олардың шағымдарын шектеп, тексеру арқылы тәртіп орнатуға, белгілі бір дәрежеде жергілікті тұрғындардың құқын ескеруге мәжбүр болды.

Отаршылдық жүйенің атқарушы органы Полиция департаментінің Верный қалалық сақшылар бөлімі арандатушылары мен құпия тыңшылары патша 
өкіметінің жарлықтарының орындалуы мен мемлекет тұғырына қауіп төнбеуін қадағалауға тиіс болды.

Әр түрлі айла-шарғылар арқылы тұрғындардың көңіл-күйі мен ісәрекеттерін анықтауға тырысты. Басты мақсат жазалаудың пәрменділігін арттыру үшін қылмыскерді табу керек болды. Жергілікті тұрғындар қадағалау мекемелері алдында үнемі қылмысты адамдай тартыншақтап жүруге тиіс болды. Полиция департаментінің қол астындағы мекемелерінің қызметі осы мақсатқа жұмылдырылды.

1907 жылдың сәуір айында Түркістан генерал-губернаторы атына «Түркістан станциясы сауда жасаушыларынан» деп қол қойылған домалақ арыз келіп түседі. Арыздағы мәлімет бойынша 1903-1905 жылдары салынып жатқан теміржолдың Түркістан учаскесінің бұрынғы подрядчигі Арифр Ходжа Азиз-Ходжиков Муцикевич ай сайын Түркістан станциясы жандармдары: вахмистр Макаровқа, унтер-офицерлер Устиновқа, Глухов, Ступанов, Козлов, Кутыров, Саксоновтарға 10 руб. ақы төлеп тұрған. Сол үшін сауда жасауға мүмкіндік алып, жандармдар жағынан қысым көрмеген. Жергілікті саудагерлерге еркін сауда жасауға жол ашылды. Участоктегі жол салу жұмысы аяқталуымен жандармдар өздерінің пайда көздерінен айырылды, төленетін ақы тоқтатылды нәтижесінде аталған жандармдар коммерсиялық кәсіпкерліктермен айналысып қызмет бабын пайдаланып, бәсекелесті азайту үшін жергілікті саудагерлерге қысым көрсетіп, қуа бастады ${ }^{7}$.

1906 жылдың наурыз айында вахмистр Макаров Илецкі қаласынан 1 вагон тұз жаздырып алып, Түркістан станциясындағы саудагерлерге 80 тиыннан сатып алуға мәжбүр етті (базарда тұздың бағасы 75 тиын болса да). Жергілікті саудагерлердің бірі Грушин осы бағамен алуға келіспегендіктен вахмистр Макаров әр түрлі қитұрқы қысым жасаулар арқылы, оның кетуіне және саудасын тоқтатуына әсер етті. Бұдан басқа вахмистр Макаров пен унтерофрицер Кутырев қазынаға тиісті сексеуілді жергілікті саудагерлерғе өткізіп, базардағы бағасы 13-15 тиын (пуды) болса да, оны 20 тиыннан сатып алуға күштеп көндіреді. Саудагер Қадыров унтер-офицер Кутыревтен сатып алмақ болғанда, вахмистр Макаров тек қана өзінікін алу керектігін нығыздап айтады. Қадыров Макаровтың мінезіне қанық болғандықтан сексеуілін айтылған бағаға алуға мәжбүр болды. Бұған ашуланған Кутырев шикі нан сатты деп Қадыровтың үстінен протокол толтырып 50 р. айып төлетті. «Ары тартсаң ат өледі, бері тартсаң арба сынадының» кері осы емес пе?!

Қызмет бабын пайдалану, сауда-саттықпен айналысу заң бойынша полиция шендегілеріне тыйым салынған әрекеттердің бірі болатын. 1890 жылғы 5 қыркүйектегі «Полиция қызметімен қатар жеке істермен айналысу ережесіне» сәйкес былай делінген:

«1. Барлық полиция қызметкерлеріне тікелей өздері немесе аралық делдалдар арқылы болсын сауда жасауға, кәсіпкерлікпен айналысуға және қызметінен тыс басқа істермен айналысуға тыйым салынады.

2. Полиция қызметкерлерінің жұбайлары мен отбасы мүшелеріне саудамен, кәсіпкерлікпен және саудаға қатысты құжаттар беретін жерде істеуге, шеберханалар ашуға тыйым салынады. Сонымен қатар полиция бақылауындағы барлық қызмет атаулылар (жезөкшелер үйін ұстау, жеңіл және ауыр арбалы арбакештер және т.б.) тыйым салынғандардың қатарына жатады».

${ }^{7}$ ӨзРОММ. 1 к., 18 т., 361 іс, 1 п. 
Міне осы ережеге қатысты баптардың Оңтүстік Қазақстандағы полиция шендері үшін құны болмаған сияқты. Оның дәлелі жоғарыдағы келтірілген мысалдар. Полиция қызметкерлері өздерінің жазаға тартылмайтынын сезініп, өлкенің толық қожайындарына айналған еді.

Жас түрікшілер комитетінің Ресейге енген үгітшілері қызметі нәтижесінде мұсылман тұрғындары арасында ислам идеясы кең тарала бастады. Жетісу өлкесіндегі осы идеяны таратушылар негізінен татарлар болды. Олардың қызметіне тыйым салу және бақылау үшін Жетісу облысының әскери губернаторы, ояз бастықтарына аса құпия хат жолдайды.

Хатта ояз бастықтарына қарамағындағы аудандағы пайда болған еш бір әрекетсіз жүргендерді және мұсылмандардың қандай да болмасын бас қосуларын астыртын бақылауға алуды бұйырады. Сол үшін Пішпек оязы бастығына екі құпия қызметкер алуға, Жаркент пен Лепсі ояз бастықтарына әрқайсысына айына 25 р. жалақы төленетін бір-біреуден құпия тыңшылар жалдауға рұқсат береді.

Бұл орынға сәйкес келетін адам табылмаған жағдайда жандармдар офицері ротмистр Астраханцев ояз бастықтарына құпия тыңшылар бөліп, саяси іздестіру ісімен таныстырады делінген болатын.

Сонымен қатар ояз бастықтары құпия тыңшылармен қатар сенімді адамдар арқылы, ояздағы христиан тұрғындары мен мұсылмандардың көңіл күйі жайында аса қауіпті қылмыстар жайында, жергілікті жердегі үстем болған өсек-аяң, әкімшіліктегі, қоғамдағы қызметкерлер арасындағы қызмет бабын пайдаланушылық туралы, жалпы қоғамдағы қобалжулар мен ой-пікірлер туралы мәлімет жинауға міндеттелді.

Барлық мәліметтер саяси іздестіруді басқарушы ротмистр Астраханцевке жіберілді. Ол мәліметтерді өңдеп аса маңызды деп тапқандарын әскери губернаторға баяндап отырды.

Жетісу облысының Батыс Қытай мен Қашқарға жақын орналасуы себепті Құлжа ауданына бөлінетін қаржының есебіндегі, ерекше шараларға жұмсалатын қаражат құпия агенттер мен тыңшыларға сый ретінде берілетін. Қашқардағы ағылшындар әрекеті жайында жіберілген тыңшылық бір мәліметке тоқталар болсақ, оны № 119-шы 1874 жылдың 12 қазанындағы генараладьютант Игнатевтің императорға жіберген рапортынан көруге болады: «ағылшын елшісі Г.Форсит Қашқарда көп жетістіктерге қол жеткізгені белгілі болды. Ол Қашқар басшысы Атталыға «Падишахтың сенімді әмірі» атағын ұсынды. Осы саясаттың дәлелі ретінде жылына оған 10000 фунт бөлінбек. Менің алған мәліметім бойынша (агент Капуке-хан) жақында Қашқардан Англия мен Константинопольге елші жіберіліп, дін жағынан сұлтанға бағыну жайында келісімге келмек. Форсит жауынгер қашқарлықтарды бізге қарсы айдап салуда еш нәрседен тайынбайды. Жаппай қарулануды ұсынып, бізге қарсы көтерілуге үндеуде. Атталықтың сеніміне кіріп алған ағылшын тыңшысы Г.Шоу саяси және коммерсиялық әрекеттерге ғана емес әскери миссияға да рұқсат алды. Бұрынғы үнді-ағылшын армиясының отставкадағы офицерлері Қашқар әскеріне нұсқаушылыққа (инструктор) ұсынылды» ${ }^{8}$. Кейінгі кезеңдегі шекарадағы жағдайлардың шиеленісе түсуі нәтижесінде, ішкі бақылау мен сыртқы барлауды күшейту үшін тыңшылар мен агенттер санын көбейту қажет болды. Олардың қазіргі кездегі жалақысы мен аса маңызды мәліметтер үшін берілетін сый ақылары мардымсыз еді. Міне, сондықтан Жетісу облысы әскери губернаторы, Түркістан генерал-губернаторына жіберген рапортында бұрынғы 
2 мың руб. орнына қазіргі кезде 6 мың руб. керек екендігін баяндайды. Оны Құлжа ауданына бөлінген қаржыдан алу мүмкін еместігі де айтылады 9 .

Мемлекеттің тыңшылық әрекеттерге жұмсаған шығындары өте зор болды. Ал ол шығындар қаншалықты ақталғандығына келетін болсақ, тыңшылардың берген мәліметтері әр қашанда шын жағдайды дәл сипаттаудан аулақ болды. Оны мұрағат деректері анық түрде дәлелдейді. Түркістан аудандық сақшылар бөліміне келіп түскен құпия анықтамаларда Жетісу облысы Пішпек ояздығында тұратын қоныстанушылар Костюков пен Ковалев 1908 ж. қаңтарында революциялық үгіт жайында мәлімет берген еді. Олар агентуралық қызметі үшін ақы сұраған. Анықтау барысында олардың Жижимовтың үстінен "Ұлы мәртебелімізді сөзбен балағаттады және революциялық үгіт жүргізді" деп жалған мәлімет бергендігі анықталды. Олардың бұндай әрекетке баруы, қоныстандыру мәселесіне байланысты кикілжіңнен туындаған ${ }^{10}$. Бұл мәлімет, тыңшылардың қызмет бабын пайдалануының тағы бір көрінісі болды.

Келесі бір деректе Тибилиси губерниясы, Гори қаласының бұрынғы тұрғыны Владимир Андреевич Давидов жалған аты «Восточный» Түркістан аудандық сақшылар бөлімінде құпия қызметте болған. Мұрағат қорларының мәліметіне талдау жасай келе, оның бопсалаумен (шантаж) айналысқандығы мәлім болды.

Жетісу облысы, Верный қаласы іздестіру пунктінде малдәрігерінің әйелі Ольга Андреевна Люблинская құпия қызметте болады. Ол негізінен социалдемократиялық партия қызметі бойынша әрекет еткен. Бірақ оның берген мәліметтері мардымсыз болып, сенім көрсетуге тұрмайтын еді. Сол себепті өзінің қызметін ұсынған жағдайда жоғарыдағы қызметкерлердің барлығынан бас тарту ұсынылды.

Осы Верный қаласының тұрғыны мещанин Кузьма Митрофранов Левинский (партиялық жалған аты «Митяй») іздестіру бөлімінің құпия қызметкері ретінде жергілікті социал-демократиялық ұйымда әрекет етіп, мәлімет жинауға тиіс еді. Бірақ ол өзіне жүктелген сенімді ақтамады. Жоғарыдағы тыңшылар тиісті жалақыларын алып отырғанымен, өз қызметтеріне жауапсыздықпен қарап, маскүнемдікке, бопсалауға, қызмет бабын пайдалануға және өздерін әшкерелеп қоюымен бөлімше үшін тиімсіз болып, олардың қызметінен бас тартылды.

Жергілікті қазақтар арасынан тыңшылыққа тартылғандар жайында мәліметтер аз, оның басты бір себебі олардың тыңшылық әрекетті ар санап одан бас тартқандығы және келіскендердің санының аздығы. Соған қарамастан бірлі-жарымды тыңшылық қызметке тартылғандар туралы мәліметтерді мұрағаттан кездестірдік. Соның бірі «Жетісу облыстық басқармасы» деген 44 қорда, Қарқаралы оязы Шұбартау болыстығының түрғыны Жиенқұлов Баймолда полицей Поляковтың, Верный іздестіру (сыск) бөлімінің бастығы Петровтың және іздестіру бөлімінің құпия тыңшысы Қасым Абдуллиннің заңсыздық әрекетеріне шағым берген. Осы қордың келесі бір құжатында Жиенқұлов Баймолда полиция шенеуніктерін балағаттады деп, Верный полициясының әкімшілік айыбына тартылған. Екі деректің бір-біріне қарама қайшы келіп тұрғанын жай көзбен-ақ байқауға болады. Әділеттік іздеп полиция қызметкерінің үстінен шағымданғанда «қарға-қарғаның көзін шұқымайтындығы» белгілі болды. Арызданушының өзі айыпқа тартылды.

Келесі бір деректе Кіші Алматы болыстығының № 10-шы ауылының тұрғыны Батырбеков Көшебай өзін Верный іздестіру бөлімінің тыңшысы Қасым 
Абдуллиннің бопсалағандығын, сол үшін арызданғанда, іздестіру бөлімінің бастығы Петровтың оны соққыға жыққандығы баяндалған. Оқ-Ақши болыстығының тұрғыны Батырхан Азимов өзін іздестіру бөлімінің тыңшысымын деп айтатын Үзгембай Байсауатовтың қысым көрсетіп салық жинағандығына арызданады.

1916 жылғы бұратаналарды тыл жұмысына алу туралы патша жарлығына байланысты қазақтар арасындағы орын алған көтеріліске қатысты зерттеу еңбектері молымен жарық көрді.

Біздің мақсатымыз Түркістан аудандық сақшылар бөлімінің құпия тыңшылары мен мәлімет берушілер арқылы алған мәліметтеріне тоқталу.

Жетісу облысы бойынша патша жарлығына сәйкес 19 бен 31 жас аралығындағы 60000 адам қара жұмысқа алынуға тиіс болды. Тыңшы «Красивый» мен мәлімет беруші «Нияздың» мәліметтерінде, қалада жұмысшы болып істейтіндер, жалшылар, қызметтерін тастап далалық аймақтарға кетуде. Верный уезінің қазақтары қара жұмысқа бармау туралы шешім қабылдады, делінсе, тыңшы «Гарды» «қала мен болыстықтардағы тараншылар жұмысқа бармайтындығын жариялады және олар жағынан қарулы қарсылық көрсетілуі мүмкін», - деп мәлімдейді.

«Алматинский» қазақтардың арасында соғысқа біз казактар сияқты әскери жасақ ретінде барамыз деушілердің басым екендігін баяндайды.

Міне, осы сияқты Түркістан аудандық сақшылар бөлімінің тыңшылары («Красивый», «Ниязбек», «Гардь», «Алматинский», «Ахмет») қазақтардың патша біздің жерімізді қоныстанушыларға тартып әперді, енді міне бізді алдыңғы шепке окоп қазуға жұмсап, өлімге айдап құтылмақшы дегендерін мәлімдейді.

Қара жұмысқа шақыру мал санағымен, егін жинаумен дәл келуіне байланысты, шаруашылықта күйзелістің орын алу мүмкіндігін де тыңшылар баяндауды ұмытпаған.

Осы жағдайларға байланысты толық мәлімет алу үшін әскери губернатор облысқа арнайы мақсатпен жіберілген тыңшылармен қатар («Ахмет») аудармашы Тоқсанбаевты Пішпек уезіне жіберсе, хат тіркеуші отставкідегі полковник Мальковскиді сарттар арасын-дағы жағдайды қадағалау үшін жолына 70 руб. беріп іссапар деп бүркемелеп жібереді.

Сонымен қатар губернатор бүлік басталған жағдайда оны басуға қажетті үш жүз казак жасақтарын жинауға өтініш жасады. Бұл мәліметтерге қарап отырып өлкедегі патша жарлығына наразылықтың өршіп тұрғандығы жайында берген тыңшылардың мәліметі неге ескерусіз қалып, Жетісудағы 1916 жылғы көтеріліске жол берілді деген сұрақ туындайды. Сірә бұл, мәліметті қарастырып шара қабылдайтын өлке басшыларының сауатсыздығы мен мәселенің қатты шиеленіскендігін есепке алмай, өз өктемдігіне толық сенімі болғандығында шығар.

1916 жылы 13 шілдеде келіп түскен агентуралық мәліметте 7 шілдеде Бұрған жайлауында барлық қазақ болыстарының өкілдері бас қосқандығы жайында баяндалады. Сөз сөйлегендер бұрынғы болыс бастығы Сәт Ниязбеков, болыс бастығы Қалшабаев және Тәнеке.

Олардың айтуы бойынша Жетісу облысы Ресейге қосылған кезде генерал Г.А. Колпаковский салтанатты түрде қырғыздар (қазақ) ешқашан әскерге алынбайды деп уәде берген еді. Бірақ уәдесін орындамады, қазақтарды алдымен ақшалай тонады, артынан киіз үй, алашасын алса, енді мұсылмандардың дені сау, жарамды дегендерін соғыс отына тастамақ. Оларды орыс солдатының алдына қойып, окоп қаздырмақ. Алдынан неміс әскері, 
артынан орыс әскері оқ жаудырып қазаға ұшыратар. Сонымен қырғыз (қазақ) халқында кәрі-құртаң мен әйелдер ғана қалады. Осылайша орыстардың ойластырған мұсылмандарды қыруы жүзеге асады. Міне, сондықтан деді сөз алған шешендер «көмусіз ит сияқты окоп қазып өлгенше, туған жердің топырағында өлгеніміз артық» деп қарсылық көрсетуге шешім қабылдады.

Шыдамы шегіне жеткен халық шоқпармен, күрек, кетпенмен, қолына ілінген байырғы құралдармен қарулы әскерге қарсы шықты. Бүлікті басудың нәтижесі аса қатігездік пен айуандықтың көрінісі болды.

Жизақ уезінің қышлақтары мен Жетісу және Сырдария облыстарындағы ондаған ауылдар жер бетінен жойылып кетті. Әйел, бала-шаға мен шалкемпірлер қойша бауыздалды. Судай болып аққан қан, құлаған саз балшық қабырғалармен араласып қойыртпақ батпаққа айналып жатты. Жер, дүниемүлік, мал, қора-қопсы мен үй-жайлар тәркіленіп көтерілісті басуға белсене қатысқан орыс кулактарына сыйға берілді. Осы 1916 жылы елді тонаудан байып алған кулактар революция кезінде де ескі заманды еске алып тонаумен айналысты.

Қорытынды. Жоғарыдағы айтылған деректердің мәліметтерін қорытар болсақ, жоғарыда жарылқаушы - қорғаушысы бар тыңшылыққа тартылғандар барлық ереже қағидаларды бұза отырып, жасырын әрекеттен ашық әрекетке көшкенін көреміз. Жергілікті тұрғындардың азаматтық құқын аяққа басып, олар үшін заң шығарушы да, оны орындататын жазалаушы да нақ осы полиция қызметкері болды. Бұл бізге деректер арқылы белгілісі ғана, ал белгісіз жақтарының жергілікті тұрғындарға қатысты қаншалықты қасіретті болғанын ойша жобалай ғана аламыз.

XX ғасырдың алғашқы жылдарынан бастап, патша өкіметі тәжірибе ретінде бірнеше шараларды қабылдаған еді, нәтижесінде полицейлік режимнің шегінен асып түскен, қасіретті тоталитаризм түнегі орнаған болатын. Тоталитаризмнің ерекшелігі, бүкіл қоғамдық институттар, қоғамдық өмірдің құбылыстары, тіпті саяси мағынасы жоқтардың өзінің полиция тарапынан қатаң бақылауға алынуында. Барлық нәрседен саяси астар іздеп, барлығы бақылауға алынады. Полицейлік режим кезінде саяси іс-әрекет заңнан тыс деп жарияланды, оны қадағалаушы қауіпсіздік органдары шексіз өкілеттілікпен қамтамасыз етілді. Мұндай жүйе шын мәнінде, жат пиғылдардың таралуынан сақтану үшін, қорғаныс ретінде құрылуға тиіс еді. Бірақ оның тоталитаризмнің неғұрлым тыңғылықты түрде жүзеге асуымен мағынасы өзгерді. Полицейлік мемлекеттің барлық қасиеттеріне ие бола отырып, одан да әрі тереңдеп қоғамның барлық саласын қауіпсіздік бөлімінің қармағына іліндірген еді. Ал оның кейінгі нәтижесі не болды дегенге жауап іздер болсақ, кеңестік өкіметінің жүргізген саясатын сараптау арқылы бағамдай аламыз.

\section{Әдебиеттер тізімі/ Список литературы}

1. Лейзерович Е.Е. Социальные и экономические итоги российской колонизации Туркестана. Тель-Авив, 2001. - 269 с.

\section{Reference}

Lejzerovich, 2001 - Lejzerovich, EE. 2001 Social'nye i ehkonomicheskie itogi rossijskoj kolonizacii Turkestana, Tel'-Aviv, 269 p. (Lejzerovich, EE 2001, Social and economic results of the Russian colonization of Turkestan, TelAviv, 269 p). (in Rus). 